\title{
WOOD-DERIVED BIOCHAR INFLUENCES NUTRIENT USE EFFICIENCY OF HEAVY METALS IN SPINACH (SPINACIA OLERACEA) UNDER GROUNDWATER AND WASTEWATER IRRIGATION
}

\author{
Sadaf Aslam GHORI ${ }^{1,2}$, Shamim GUL ${ }^{1,}{ }^{*}$, Saniya TAHIR ${ }^{2}$, Meenah SOHAIL ${ }^{2}$, \\ Saira BATOOL ${ }^{2}$, Muhammad Naeem SHAHWANI ${ }^{4}$, Gul BANO ${ }^{3}$, \\ Mujeeb-ur-Rehman BUTT 5
}

${ }^{1}$ Department of Botany, University of Balochistan, Saryab Road, Quetta, 87300, Balochistan, Pakistan

${ }^{2}$ Department of Environmental Sciences, Sardar Bahadur Khan Women's University, Brewery Road, 87300, Quetta, Balochistan, Pakistan

${ }^{3}$ Department of Natural Resource Sciences, Macdonald Campus, McGill University,

21111 Lakeshore Road, Ste-Anne-de-Bellevue, H9X 3V9, Quebec, Canada

${ }^{4}$ Faculty of Life Sciences and Informatics, Balochistan University of Information Technology,

Engineering and Management Sciences, Takatoo Campus, Airport Road, Baleli, Quetta, Balochistan, Pakistan

${ }^{5}$ Pakistan Council of Science and Industrial Research, Mastung Road, 87300, Quetta, Balochistan, Pakistan

Received 11 April 2017; accepted 06 February 2019

\begin{abstract}
Present study analysed the influence of slow-pyrolyzed wood-derived biochar on growth performance and heavy metal accumulation in the leaves of spinach grown under groundwater and wastewater irrigation. Biochar was applied in soil as 5\% ( 30 thha $\left.{ }^{-1}\right)$ and 10\% ( 60 thha $\left.{ }^{-1}\right)$ amendment. According to results, plant biomass was significantly higher under wastewater than groundwater irrigation. Biochar amendment increased significantly the aboveground plant biomass and root biomass and promoted water use efficiency (WUE). Under groundwater irrigation, biochar amendment at $10 \%$ application rate, increased the leaf area index $(\mathrm{P}<0.05)$, while amendment of biochar at all application rates significantly reduced leaf area index under wastewater irrigation $(\mathrm{P}<0.05)$. Application of biochar also reduced accumulation of rhizosphere soil around roots under wastewater irrigation, indicating less exudate production in the rhizosphere of plants. Biochar significantly reduced the concentration of copper $(\mathrm{Cu})$ in under wastewater irrigation. Biochar increased the nutrient use efficiency (NUE) of plants for zinc ( $\mathrm{Zn}$ ) and $\mathrm{Cu}$ under wastewater irrigation.
\end{abstract}

Keywords: wood biochar, rhizosphere soil, water use efficiency, nutrient use efficiency, heavy metal accumulation, spinach.

\section{Introduction}

Sewage wastewater irrigation to agricultural lands is a common practice in developing countries as a waste management, as an alternative to inorganic fertilizers and to save fresh water for human consumption. Wastewater has high concentration of nutrients and heavy metals that are absorbed by plants in access amounts and ultimately consumed by humans and domestic animals, thus posing serious health problems (Raja et al., 2015).

Management measures related to reduce the accumulation of heavy metals in plants irrigated with wastewater are therefore important to be taken to reduce heavy-metal-induced human health issues. This can be achieved via (1) improving the water use efficiency (WUE) and nutrient use efficiency (NUE) of plants so that they require less water and nutrients to grow and (2) to amend a porous matter in soil that have high adsorption capacity for nutrients and heavy metals. Biochar is a pyrogenous highly porous biomass and is used in agricultural lands as soil conditioner (Gul, Whalen, Thomas, Sachdeva, \& Deng, 2015; Gul \& Whalen, 2016). It improves the physico-chemical and biological properties of soil, enhances the WUE and NUE of crops (Aller, Rathke, Laird, Cruse, \& Hatfield, 2017; Gul et al., 2015; Gul \& Whalen, 2016) and tend to reduce accumulation of heavy metals in plants (Lucchini, Quilliam, DeLuca, Vamerali, \& Jones, 2014; Zhang et al., 2016) as it has high adsorption capacity for heavy metals from soil (Baltrėnaitè, Baltrènas, \& Lietuvninkas, 2016).

${ }^{*}$ Corresponding author. E-mail: shamim.gul@mail.mcgill.ca 
Spinach is considered to be the most consumed leafy green vegetable by the Asians and is a rich source of many vitamins and minerals. The information about influence of wood-derived biochar amendment in soil on the growth performance and heavy metal accumulation in this vegetable under wastewater irrigation can provide an insight into its applicability in agricultural lands. This study aims to evaluate influence of wood-derived biochar on the growth performance (i.e. biomass production, leaf area index, rhizosphere soil accumulation, water use efficiency (WUE), nutrient use efficiency (NUE) for heavy metals) and accumulation of copper $(\mathrm{Cu})$, iron $(\mathrm{Fe})$, nickel $(\mathrm{Ni})$ and zinc ( $\mathrm{Zn})$ in aboveground biomass of spinach under groundwater and wastewater irrigation.

\section{Materials and methods}

\subsection{Biochar}

Slow pyrolyzed, wood-derived-biochar obtained from timber market was used for this study. The biochar was produced in kilns, therefore the pyrolysis temperature ranges between $350-500{ }^{\circ} \mathrm{C}$ (Mia et al., 2015). The biochar underwent crushing followed by passing through $2 \mathrm{~mm}$ and $0.65 \mathrm{~mm}$ mesh sieves to obtain two particle sizes i.e. $2 \mathrm{~mm}-0.65$ and $<0.65 \mathrm{~mm}$. Biochar was subjected to $\mathrm{pH}$ analysis according to the protocol of Chintala et al. (2014) by dissolving $1 \mathrm{~g}$ biochar into $10 \mathrm{ml} \mathrm{H}_{2} \mathrm{O}$, well mixed and analyzed after $18 \mathrm{~h}$. $1 \mathrm{~g}$ biochar was combusted at $500{ }^{\circ} \mathrm{C}$ for five hours and the ash was dissolved in $0.302 \mathrm{M} \mathrm{HCl}$ (diluted from $37 \%$ pure $\mathrm{HCl}$ calculated from https://www. sigmaaldrich.com/chemistry/stockroom-reagents/learning-center/technical-library/molarity-calculator.html) for assessment of heavy metal concentration (e.g. Rechcigl \& Payne, 1989).

\subsection{Experimental design}

Sandy loam soil obtained from the top $0-5 \mathrm{~cm}$ depth of the garden of Sardar Bahadur Khan Women University was used for this study. Soil was air-dried and passed through $2 \mathrm{~mm}$ mesh sieve. Small sized plastic pots i.e. $15 \mathrm{~cm}$ diameter and $20 \mathrm{~cm}$ height were filled with soil. The positive influence of biochar on plant growth performance and soil quality is reported to be happened when biochar is co-amended with organic (e.g. compost or manure) or inorganic fertilizer (Gul et al., 2015; Gul \& Whalen, 2016). Therefore, the soil of each pot (including control treatment) was amended with $2 \%\left(\sim 12 \mathrm{t} \cdot \mathrm{ha}^{-1}\right)$ air dried, crushed mixture of cow and sheep manure (mixed as 1:1 ratio) as an organic fertilizer.

The experiment layout and abbreviation of each treatment is provided in Table 1. There were ten treatments; five treatments for groundwater and five treatments for wastewater irrigation were (1) soil without biochar, 2) soil with 5\% ( 30 tha ${ }^{-1}$; conversion factor based on Ameloot et al., 2014) amendment of large-sized biochar, soil with 10\% ( 60 th ha ${ }^{-1}$; conversion factor based on Ameloot et al., 2014) amendment of large-sized biochar, soil with $5 \%$ amendment of small-sized biochar and soil with 10\% amendment of small-sized biochar (GW0.65, 10). There were 6 replications for spinach growth performance parameters and out of six, three replications were taken into account for heavy metal accumulation assessment.

Table 1. Experiment layout and abbreviations of treatments

\begin{tabular}{|c|c|c|c|}
\hline $\begin{array}{l}\text { Irrigation } \\
\text { treatments }\end{array}$ & $\begin{array}{c}\text { Biochar } \\
\text { particle size }\end{array}$ & $\begin{array}{l}{ }^{1} \text { Biochar amend- } \\
\text { ment rate }(\%)\end{array}$ & Abbreviations \\
\hline $\begin{array}{l}\text { Groundwater } \\
\text { control }\end{array}$ & N/A & 0 & GW \\
\hline $\begin{array}{l}\text { Wastewater } \\
\text { control }\end{array}$ & N/A & 0 & SW \\
\hline \multirow{4}{*}{ Groundwater } & \multirow{2}{*}{$\begin{array}{l}2 \mathrm{~mm} \\
\text { Particle size } \\
\text { biochar }\end{array}$} & 5 & GW2, 5 \\
\hline & & 10 & GW2, 10 \\
\hline & \multirow{2}{*}{$\begin{array}{l}<0.65 \mathrm{~mm} \\
\text { Particle size } \\
\text { biochar }\end{array}$} & 5 & GW0.65, 5 \\
\hline & & 10 & GW0.65, 10 \\
\hline \multirow{4}{*}{ Wastewater } & \multirow{2}{*}{$\begin{array}{l}2 \mathrm{~mm} \\
\text { Particle size } \\
\text { biochar }\end{array}$} & 5 & SW2, 5 \\
\hline & & 10 & SW2, 10 \\
\hline & \multirow{2}{*}{$\begin{array}{l}<0.65 \mathrm{~mm} \\
\text { Particle size } \\
\text { biochar }\end{array}$} & 5 & SW0.65, 5 \\
\hline & & 10 & SW0.65, 10 \\
\hline
\end{tabular}

Note: ${ }^{1}$ the mixture of air-dried cow and sheep manure (mixed as 1:1 ratio) was used as source of organic fertilizer in all treatments.

\subsection{Cultivation, harvest and assessment of growth performance parameters of spinach}

The "green variety" of spinach (Spinacia oleracea L.), obtained from a local market was taken into account for this study. The pots of all treatments were moistened to nearly $100 \%$ water filled pore space (WFPS) before seeds were sowed, to provide wet soft bed for seed germination. Afterwards seeds were broad casted over soil in mid of May and placed at room temperature inside of laboratory for germination. After one week of seed germination, pots were shifted outside environment, in the open place (without tree-shaded), but shaded with net fabric to avoid heat shock to plants. After two weeks of seed germination, the pots were thinned and maintained to 5 plants per pot. Afterwards till harvesting, pots were irrigated with same amount of water at alternate days and once in a week the water contents were adjusted to $~ 60 \%$ WFPS as described in (Gul \& Whalen, 2013). The pots of wastewater treatment received only wastewater irrigation after two weeks of seed germination. Wastewater was obtained from Sabzal road, Quetta, Balochistan, Pakistan. The concentration of heavy metals in wastewater and groundwater is provided Table 2.

Pots were sprayed once with the pesticide to prevent damage of leaves due to pests. Before harvesting, the height of plants were measured. Pots were harvested in the first week of August. Above ground plant biomass and roots 
Table 2. $\mathrm{pH}$, concentration of $\mathrm{Cu}, \mathrm{Fe}, \mathrm{Mn}$ (manganese), $\mathrm{Ni}$, $\mathrm{Zn}, \mathrm{Cr}$ (chromium) and $\mathrm{Mg}$ (magnesium) in groundwater, wastewater, biochar and manure

\begin{tabular}{|l|c|c|c|c|}
\hline Element & $\begin{array}{c}\text { Ground- } \\
\text { water } \\
(\mathrm{ppm})\end{array}$ & $\begin{array}{c}\text { Waste- } \\
\text { water } \\
(\mathrm{ppm})\end{array}$ & $\begin{array}{c}\text { Biochar } \\
\left(\mathrm{mg}^{-1}\right)\end{array}$ & $\begin{array}{c}\text { Manure } \\
\left(\mathrm{mg}^{-1}\right)\end{array}$ \\
\hline $\mathrm{pH}$ & nd & nd & 8.730 & nd \\
\hline $\begin{array}{l}{ }^{1} \text { Electrical } \\
\text { conductivity } \\
(\mu \mathrm{s})\end{array}$ & nd & nd & 2.38 & nd \\
\hline $\begin{array}{l}{ }^{1} \text { Organic } \\
\text { carbon }(\%)\end{array}$ & nd & nd & 71 & 77 \\
\hline${ }^{1} \mathrm{Ash}(\%)$ & nd & nd & 29 & 23 \\
\hline $\mathrm{Cu}$ & - & - & - & 3.96 \\
\hline $\mathrm{Fe}$ & - & 3.582 & 0.627 & $\mathrm{nd}$ \\
\hline $\mathrm{Mn}$ & 0.487 & 0.331 & 0.006 & 1.872 \\
\hline $\mathrm{Ni}$ & 0.730 & 4.88 & 0.091 & 90.72 \\
\hline $\mathrm{Zn}$ & - & 0.138 & 0.024 & 1.616 \\
\hline $\mathrm{Cr}$ & 87.5 & 111.7 & 2.536 & $\mathrm{nd}$ \\
\hline $\mathrm{Mg}$ & 3.779 & 0.038 & 31.72 \\
\hline
\end{tabular}

Note: the 1 indicates data presented in Haider et al. (2018) (these authors used the same biochar as in the present study), nd indicates no data and - indicates concentration below detection limit.

were separated, soil from the roots was removed with water, the biomass was oven-dried at $60^{\circ} \mathrm{C}$ for 48 hours and dry biomass was measured.

Plants were irrigated with ground and sewage water effluent. Due to arid climate of Quetta pots were given $80 \mathrm{ml}$ of water on daily basis, once in a week pots were weighed and maintained at $60 \%$ water filled pore space (WFPS) as described in Gul and Whalen (2013) to measure the water use efficiency in different treatments. While pots under wastewater irrigation treatment was provided with groundwater daily as described above and with sewage water effluent once in a week to keep plant growing properly. The water use efficiency (WUE) of plants was measured by using following equation (Aller et al., 2011) as:

$$
\text { WUE }=\frac{\text { Plant biomass }}{\text { water loss through evapotranspiration }} .
$$

Rhizosphere soil was collected as described in Gul and Whalen (2013). After harvesting of aboveground plant biomass, pots were cut from two sides and the soil-root system was removed carefully. The WFPS was $~ 45-50 \%$. Bulk soil was removed with slight tapping soil-root system, roots were removed and shaken to remove bulk soil. The soil that was strongly adhered to the roots was considered as rhizosphere soil Gul and Whalen (2013). Roots were placed in $50 \mathrm{ml}$ of distilled water to remove rhizosphere soil. Rhizosphere soil was subsequently air dried for 48 hours followed by oven drying at $60^{\circ} \mathrm{C}$ and weight was taken. Roots were also dried at $60^{\circ} \mathrm{C}$ for 48 hours and weighted. Rhizosphere soil was calculated as $\mathrm{g}$ rhizosphere soil g ${ }^{-1}$ root biomass (Prendergast-Miller, Duvall, \& Sohi, 2013). The soil that was strongly adhered to the roots was considered as rhizosphere soil Gul and Whalen (2013).

\subsection{Assessment of heavy metal accumulation and NUE of spinach}

To assess heavy metals in aboveground plant biomass, sample digests and analysis was carried out by using flame Atomic Absorption AA-7000 (Shimadzu) following protocol of Estefan, Sommer, and Ryan (2013). The digest for biochar was prepared by dry ash digestion (e.g. Rechcigl \& Payne, 1989) as described above.Roots were placed in $50 \mathrm{ml}$ of distilled water to remove rhizosphere soil. Rhizosphere soil was subsequently air dried for 48 hours followed by oven drying at $60^{\circ} \mathrm{C}$ and weight was taken. Roots were also dried at $60^{\circ} \mathrm{C}$ for 48 hours and weighted. Rhizosphere soil was calculated as $\mathrm{g}$ rhizosphere soil $\mathrm{g}^{-1}$ root biomass (Prendergast-Miller et al., 2013).

The NUE for a given nutrient as "nutrient efficiency ratio" in plant tissues was calculated as described in Gul and Whalen (2016) as:

$$
\text { NUE }=\frac{\text { Plant biomass }}{\text { Amount of nutrient in plant tissue }} .
$$

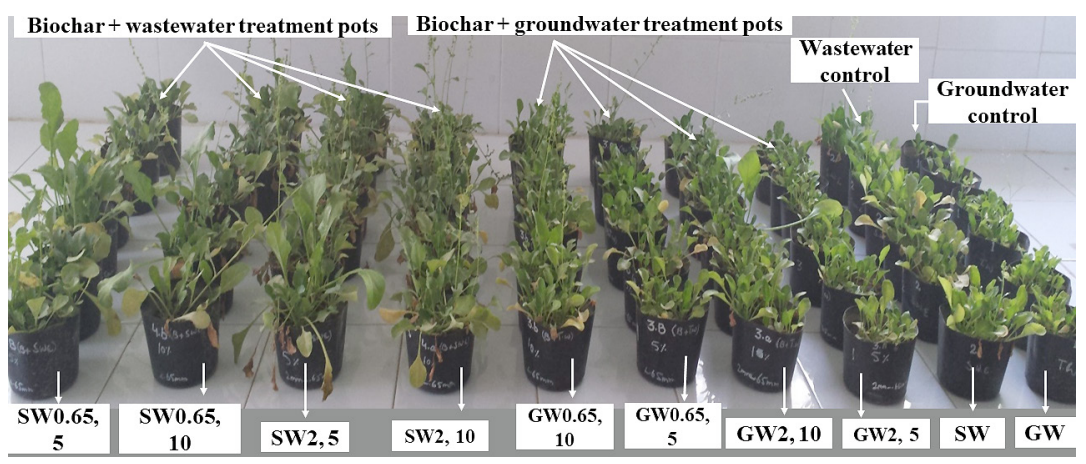

Figure 1. Pots grown with spinach under different treatments GW-ground water, SW-wastewater,

2, 5-soil amended with large particle size biochar at 5\% amendment rate,

2, 10-soil amended with large particle size biochar at $10 \%$ amendment rate,

0.65 , 5-soil amended with small particle size biochar at $5 \%$ amendment rate,

$0.65,10$-soil amended with small particle size biochar at $10 \%$ amendment rate.

Bars with different letters indicate significant difference at $\mathrm{P} \leq 0.05$ 


\subsection{Bioaccumulation factor (or Bioconcentration factor) of heavy metals}

The bioaccumulation was calculated as concentration of heavy metal in plant tissue/concentration of heavy metal in water sample (Yabanli, Yozukmaz, \& Sel, 2014).

\subsection{Statistical analysis}

All the data subjected to normal distribution assessment by using D/Agostino-Pearson K2 test. All the data sets were normally distributed and were subsequently subjected to analysis of variance (ANOVA) followed by least significant difference (LSD) test. All the data analysis carried out using CoStat software version 6.311.

\section{Results}

\subsection{Plant growth performance}

Application of biochar influenced plant growth performance. Higher application rates of biochar significantly increased plant height in groundwater irrigation treatment $(\mathrm{P}<0.05$, Figure 1 and Figure 2). Biochar reduced the leaf area index of spinach under groundwater and wastewater irrigation except for $10 \%$ large-sized biochar amendment in groundwater treated soil (Figure 2).

Plant biomass was significantly increased by biochar application under both groundwater and wastewater irrigation except for the large sized biochar applied at 5\% rate in groundwater treated soil (Figure 2). The WUE of plants were significantly improved by biochar amendment at higher application rates in groundwater treated soils and at both biochar application rates in wastewater treated soils (Figure 2).

Biochar amendment at both application rates significantly increased root biomass and accumulation of soil in rhizosphere of plants irrigated with groundwater $(\mathrm{P}<0.05$; Figure 3$)$. For the wastewater irrigated treatment, root biomass and accumulation of soil in the rhizosphere was reduced in response to the large-sized biochar applied as $10 \%$ amendment, small-sized biochar applied at $5 \%$ amendment also reduced accumulation of soil in the rhizosphere (Figure 3).

Other biochar treatments had no influence on root biomass and accumulation of soil in the rhizosphere of spinach irrigated with wastewater (Figure 3).

\subsection{Accumulation of trace elements in aboveground plant biomass}

Application of biochar significantly increased the concentration of $\mathrm{Zn}$ and $\mathrm{Ni}$ in aboveground plant biomass of spinach irrigated with groundwater $(\mathrm{P}<0.05)$ while plants grown under wastewater irrigation showed no response to the application of biochar in this regard (Figure 4). Large-sized biochar applied at 10\% rate and small-sized biochar at both application rates significantly increased the concentration of $\mathrm{Cu}$ in aboveground plant biomass of spinach grown under groundwater irrigation while smallsized biochar applied at $10 \%$ rate significantly decreased its concentration in spinach irrigated with wastewater $(\mathrm{P}<0.05$; Figure 4).

Biochar had no influence on the accumulation of Fe in the aboveground plant biomass of spinach irrigated with
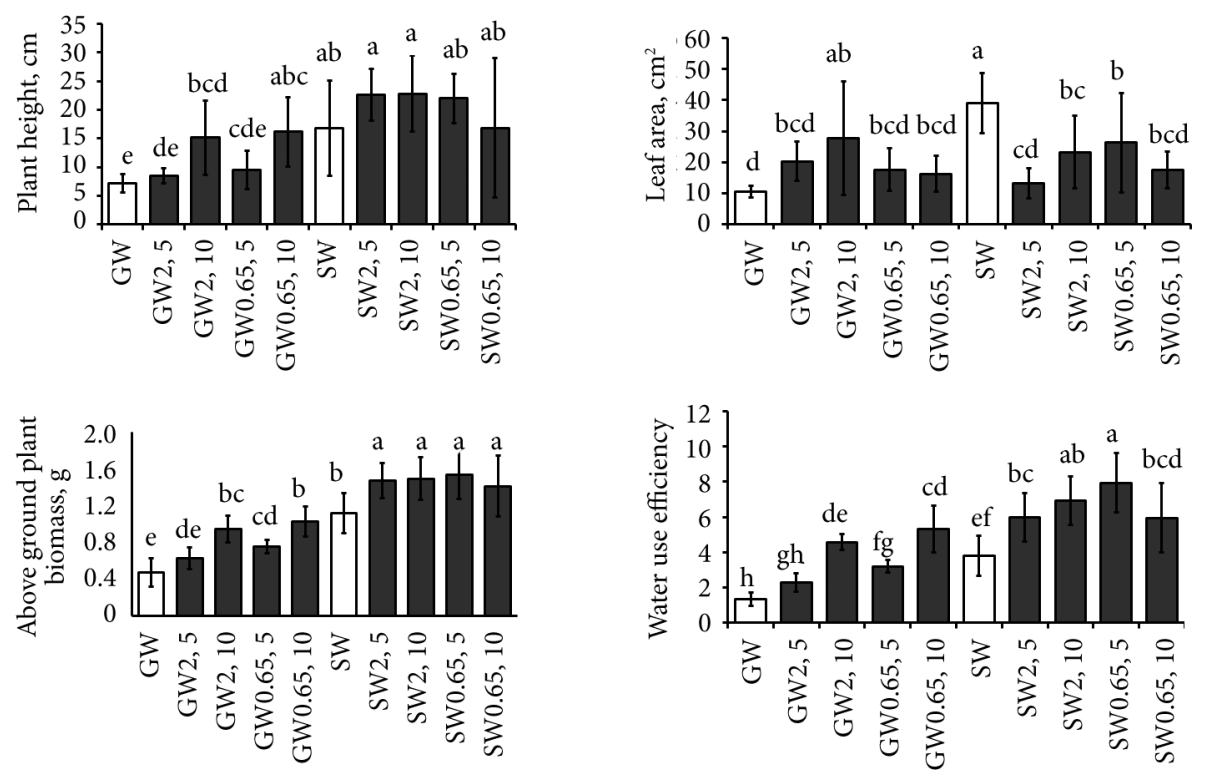

Figure 2. Mean $\pm \mathrm{SD}$ of plant height $(\mathrm{cm})$, leaf area $\left(\mathrm{cm}^{2}\right)$, above ground biomass dry weight $(\mathrm{g})$ and water use efficiency of spinach in response to various treatments; GW-ground water, SW-wastewater, 2, 5-soil amended with large particle size biochar at 5\% amendment rate, 2, 10-soil amended with large particle size biochar at 10\% amendment rate, 0.65 , 5-soil amended with small particle size biochar at 5\% amendment rate, 0.65 , 10-soil amended with small particle size biochar at 10\% amendment rate. Bars with different letters indicate significant difference at $\mathrm{P} \leq 0.05$ 

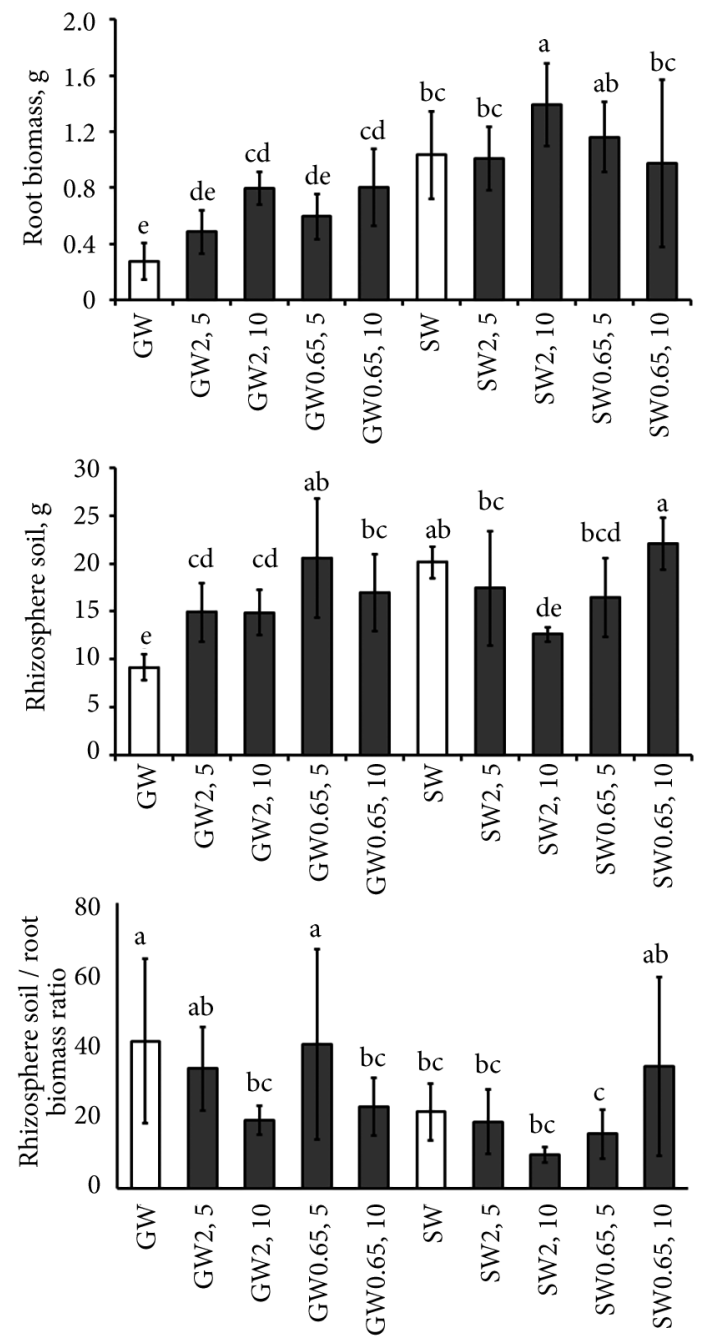

Figure 3. Mean \pm SD of root biomass (g), rhizosphere soil accumulation around roots $(\mathrm{g})$ and rhizosphere soil/root biomass ratio of spinach in response to various treatments; GW-ground water, SW-wastewater, 2, 5-soil amended with large particle size biochar at $5 \%$ amendment rate, 2,10 -soil amended with large particle size biochar at $10 \%$ amendment rate, $0.65,5$-soil amended with small particle size biochar at $5 \%$ amendment rate, $0.65,10$-soil amended with small particle size biochar at $10 \%$ amendment rate. Bars with different letters indicate significant difference at $\mathrm{P} \leq 0.05$

groundwater and wastewater (Figure 4). The NUE for Zn and $\mathrm{Cu}$ was improved by biochar application rate in spinach irrigated with wastewater $(\mathrm{P}<0.05$; Figure 5$)$.

The bioaccumulation factor (or bioconcentration factor calculated as concentration of heavy metal in plant tissue/concentration of heavy metal in water sample (Yabanli et al., 2014), varied for different heavy metals. The bioaccumulation factor of spinach was in the order of $\mathrm{Ni}$ $>\mathrm{Fe}>\mathrm{Zn}$ (Table 3). The accumulation factor of $\mathrm{Zn}$ was greater in groundwater-irrigated plants than wastewatertreated plants $(\mathrm{P}<0.05)$ and was enhanced with the application of biochar $(\mathrm{P}<0.05$; Table 3$)$. In contrast, the bioaccumulation factor for $\mathrm{Ni}$ was higher in plants irrigated with wastewater as compared to the ones irrigated with groundwater and was enhanced in response to the amendment of biochar under both irrigation treatments
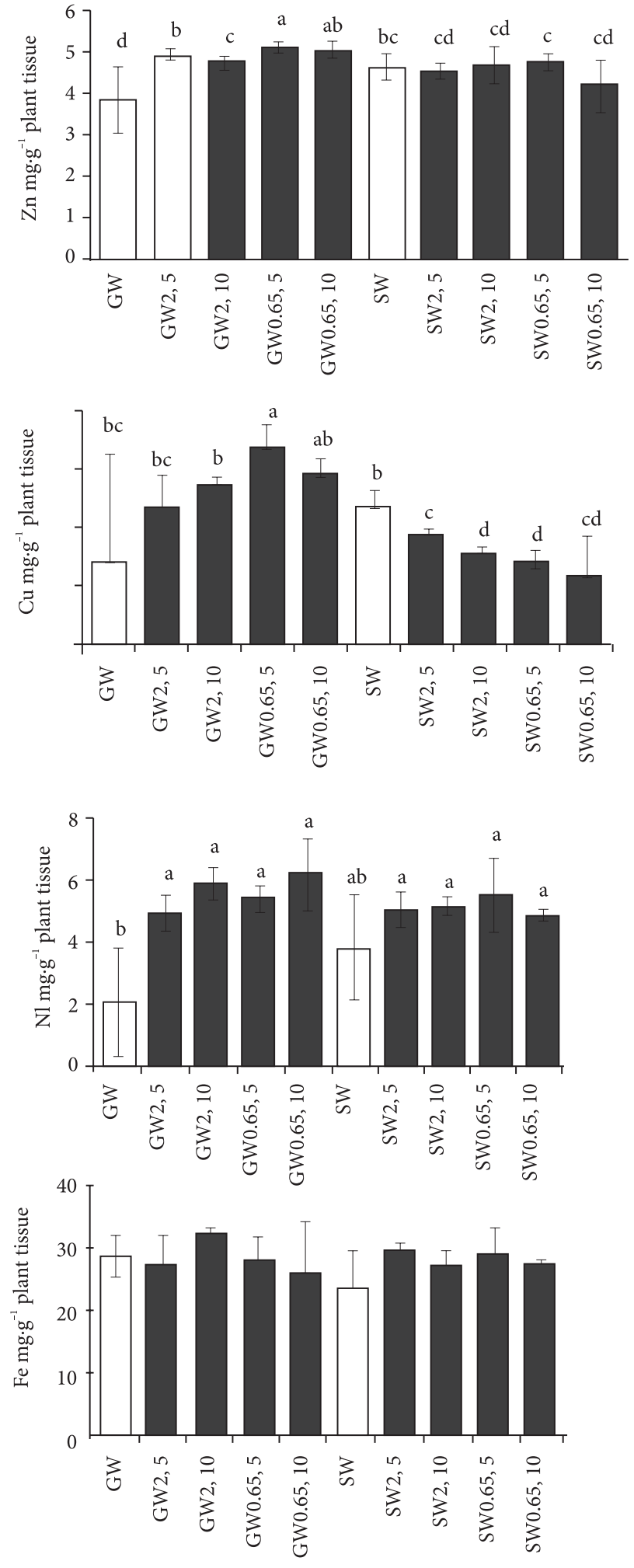

Figure 4. Mean \pm SD of heavy metal accumulation in aboveground biomass of spinach for heavy metals in response to various treatments; GW-ground water, SW-wastewater,

2, 5-soil amended with large particle size biochar at 5\% amendment rate, 2, 10-soil amended with large particle size biochar at $10 \%$ amendment rate, $0.65,5$-soil amended with small particle size biochar at $5 \%$ amendment rate,

$0.65,10$-soil amended with small particle size biochar at $10 \%$ amendment rate. Bars with different letters indicate significant difference at $\mathrm{P} \leq 0.05$ 
$(\mathrm{P}<0.05$; Table 3). Likewise, the accumulation factor for Fe of plants under wastewater irrigation increased significantly in response to amendment of biochar $(\mathrm{P}<0.05$; Table 3).

\section{Discussion}

\subsection{Plant growth performance}

As compared to control, biochar amendment increased the aboveground biomass of spinach by $37 \%$ to $54 \%$ under groundwater irrigation and by $21-27 \%$ under wastewater irrigation. Wastewater also improved the biomass production by $57.4 \%$ than control. Results of Dharmakeerthi, Chandrasiri, and Edirimanne (2012) are consistent with the results of current study as rubber wood biochar increased the biomass of Hevea brasiliensis by $29 \%$ to $61 \%$ as compared to control. Yamato, Okimori, Wibowo, Anshori, and Ogawa (2006) reported 50\% increase in maize yield in response to the amendment of biochar produced from Acacia magnum bark.

Biochar amendment did not influence the leaf area index of spinach irrigated with groundwater except for large-sized biochar applied at $10 \%$ amendment rate, which increased leaf area index.

However, under wastewater irrigation, amendment of biochar significantly reduced leaf area index although
Table 3. Bioaccumulation factor (mean \pm SD) (or bioconcentration factor) (calculated as concentration of heavy metal in plant tissue/concentration of heavy metal in water sample (Yabanli et al., 2014)) of $\mathrm{Zn}, \mathrm{Ni}$ and Fe in leaves of spinach under groundwater and wastewater irrigation

\begin{tabular}{|l|c|c|c|c|}
\hline Treatment & $\mathrm{Zn}$ & $\mathrm{Ni}$ & $\mathrm{Cu}$ & $\mathrm{Fe}$ \\
\hline GW & $5.25 \pm 1.06^{\mathrm{d}}$ & $4.20 \pm 3.54^{\mathrm{c}}$ & $\mathrm{nd}$ & $\mathrm{nd}$ \\
\hline GW2, 5 & $6.71 \pm 0.00^{\mathrm{b}}$ & $10.1 \pm 1.18^{\mathrm{b}}$ & nd & nd \\
\hline GW2, 10 & $6.50 \pm 0.12^{\mathrm{c}}$ & $12.1 \pm 1.04^{\mathrm{b}}$ & nd & nd \\
\hline GW0.65, 5 & $6.98 \pm 0.13^{\mathrm{a}}$ & $11.1 \pm 0.86^{\mathrm{b}}$ & nd & nd \\
\hline GW0.65, 10 & $6.86 \pm 0.18^{\mathrm{a}}$ & $12.7 \pm 2.36^{\mathrm{b}}$ & nd & nd \\
\hline SW & $0.94 \pm 0.05^{\mathrm{e}}$ & $11.5 \pm 5.05^{\mathrm{b}}$ & nd & $6.64 \pm 1.53^{\mathrm{ab}}$ \\
\hline SW2, 5 & $0.92 \pm 0.04^{\mathrm{e}}$ & $15.1 \pm 1.76^{\mathrm{a}}$ & nd & $8.26 \pm 0.11^{\mathrm{a}}$ \\
\hline SW2, 10 & $0.95 \pm 0.09^{\mathrm{e}}$ & $15.5 \pm 0.87^{\mathrm{a}}$ & nd & $7.55 \pm 0.50^{\mathrm{b}}$ \\
\hline SW0.65, 5 & $0.97 \pm 0.03^{\mathrm{e}}$ & $16.6 \pm 3.58^{\mathrm{a}}$ & nd & $8.01 \pm 1.11^{\mathrm{ab}}$ \\
\hline SW0.65, 10 & $0.85 \pm 0.12^{\mathrm{e}}$ & $14.6 \pm 0.50^{\mathrm{a}}$ & nd & $7.64 \pm 0.14^{\mathrm{b}}$ \\
\hline
\end{tabular}

Note: values within column followed by different letters are significantly different at $\mathrm{P}<0.05$, nd represents no data (as $\mathrm{Cu}$ and Fe was not detectable in groundwater).

irrigation of plants with wastewater without biochar amendment enhanced leaf area index by $73.3 \%$ than control. Despite of a significant increase in aboveground plant
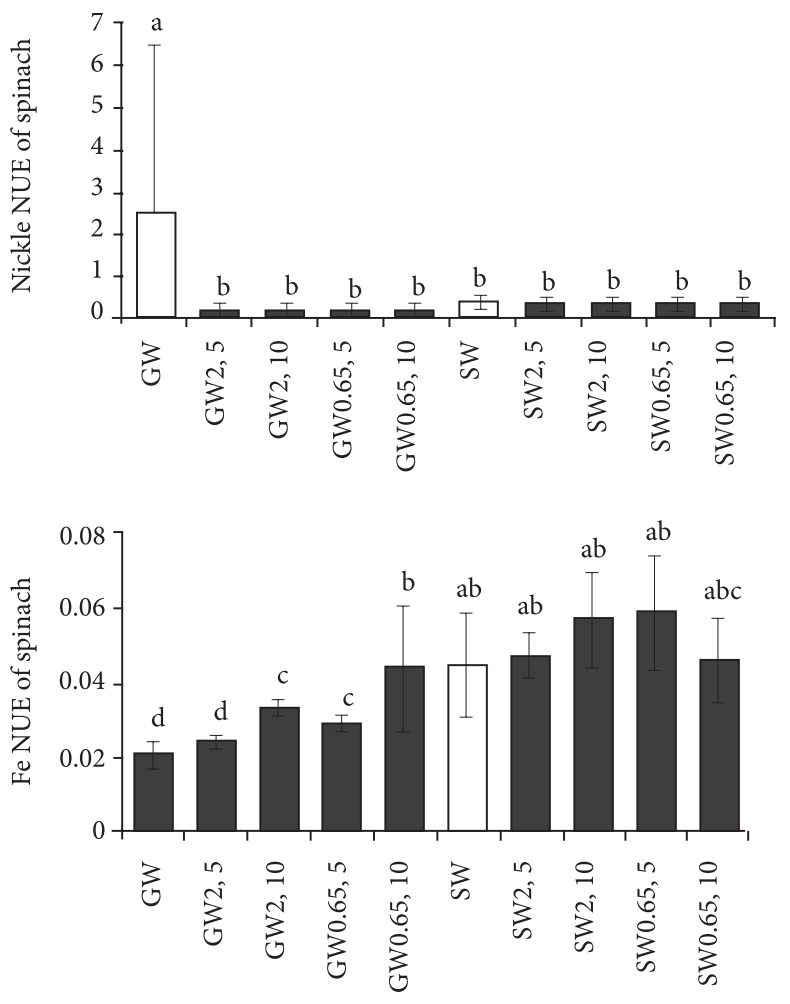

Figure 5. Mean \pm SD of nutrient use efficiency (NUE) of spinach for heavy metals in response to various treatments; GW-ground water, SW-wastewater, 2, 5-soil amended with large particle size biochar at 5\% amendment rate,

2, 10-soil amended with large particle size biochar at $10 \%$ amendment rate, $0.65,5$-soil amended with small particle size biochar at $5 \%$ amendment rate, $0.65,10$-soil amended with small particle size biochar at $10 \%$ amendment rate. Bars with different letters indicate significant difference at $\mathrm{P} \leq 0.05$ 
biomass, the reduction in leaf area index of spinach in response to biochar amendment under wastewater irrigation indicate that biochar enhanced the growth of stems. There is no empirical evidence to date to support our findings about the negative influence of biochar under wastewater irrigation on leaf area of spinach. However, Liu et al. (2016) reported that biochar derived from birch wood reduced the leaf area index of potato inoculated with arbuscular mycorrhizal fungi. They attributed this negative effect to the biochar toxicity and biochar-induced reduction in the bioavailability of nitrogen and phosphorus to plants. Mensah and Okonwu (2016) also reported that biochar derived from Pentaclethra Macrophylla reduced leaf area of Capsicum annuum when applied at higher application rates i.e. $30 \%$ amendment.

Since biochar amendment significantly increased aboveground plant biomass, we cannot attribute the negative influence of biochar on leaf area index of the plants irrigated with wastewater as the result of nutrient limitation. There may be the tradeoff between plant biomass production and leaf area index of the plants irrigated with wastewater in response to biochar amendment.

Application of biochar enhanced WUE of spinach $58.5 \%$ to $75 \%$ under groundwater irrigation and $36-52 \%$ under wastewater irrigation as compared to control treatments. Furthermore, the WUE of spinach of wastewater control treatment was $66 \%$ higher than the spinach of groundwater control treatment. Our results are consistent with previous findings that amendment of biochar enhance the WUE of crops (Lusiba, Odhiambo, \& Ogola, 2018). This findings has implications regarding reduction in the need of water for plant growth by using biochar as an amendment in agricultural soil of developing countries where farmers rely on wastewater irrigation.

Wastewater irrigation increased the root biomass by $78 \%$ as compared to the plants of groundwater control treatment. Biochar amendment at higher rates increased root biomass than control treatments by $65 \%$ for groundwater treatment and $26 \%$ for wastewater irrigation. Plants under wastewater irrigation also had $\sim 55 \%$ higher rhizosphere soil than the plants of groundwater control treatment. This indicates that wastewater improved root growth and rhizosphere soil accumulation. Biochar amendment increased significantly soil in rhizosphere by $38-55 \%$ for groundwater treated plants while in wastewater irrigated soils, biochar amendment did not show any increase in this regard. However, the large-sized biochar applied as $10 \%$, reduced significantly the soil in the rhizosphere. Prendergast-Miller et al. (2013) reported 13.5\% higher rhizosphere soil accumulation in spring barely grown under fresh water irrigation in response to Miscanthusderived biochar as compared to control. Rhizosphere soil ranges from $1 \mathrm{~mm}$ to few $\mathrm{mm}$ soil attached to roots, and serve a source of water and nutrients to roots ( $\mathrm{Li}$ et al., 2015). Nutrient availability to plants is directly dependent upon the available nutrient in the rhizosphere. The reduced soil in the rhizosphere of plants irrigated with wastewater than groundwater treatment may be attributed to the higher concentration of nutrients in wastewater of Quetta city (Table 1), which might had reduced the need of plant roots to acquire nutrients with the help of microorganisms by secreting rhizodeposits (Pivato et al., 2017). In our study, although the rhizosphere soil:root biomass ratio was not increased by biochar amendment, greater soil accumulation in the rhizosphere in response to biochar amendment in soil have implications for improving soil structure and enhancing soil carbon sequestration.

\subsection{Accumulation of trace elements in aboveground plant biomass}

Spinach is reported to accumulate more trace elements, being a leafy vegetable (Qureshi, Hussain, Ismail, \& Khan, 2016). In our study, biochar increased significantly the accumulation of $\mathrm{Zn}, \mathrm{Ni}$ and $\mathrm{Cu}$ in aboveground biomass of spinach irrigated with groundwater while in wastewater treatment, application of biochars reduced significantly the concentration of $\mathrm{Cu}$ in aboveground plant biomass. Nigussie, Kissi, Misganaw, and Ambaw (2012) also observed no influence of biochar amendment on accumulation of chromium $(\mathrm{Cr})$ in lettuce grown in soil low to moderately contaminated with $\mathrm{Cr}$ but reduced accumulation in high Cr-polluted soil. Lucchini et al. (2014) also reported that the repeated application of wood-derived biochar for two years in field at various application rates (25 and $50 \mathrm{t} \cdot \mathrm{ha}^{-1}$ ) did not influence the accumulation of heavy metals i.e. arsenic (As), cadmium (Cd), $\mathrm{Cu}, \mathrm{Ni}$, lead ( $\mathrm{Pb}$ ) and $\mathrm{Zn}$ in the leaves of bean plants. Wagner and Kaupenjohann (2013) found that biochar produced from maize straw applied at $0,1,2.5$ and $5 \%$ in pots reduced the concentration of $\mathrm{Zn}$ and $\mathrm{Cd}$ but did not reduced the concentration of $\mathrm{Cu}$ and $\mathrm{Pb}$ in oat grains irrigated with wastewater. More recent finding of Tahir et al. (2018) demonstrate that application of cow-manure-derived biochar applied as 3\%, 5\% and $10 \%$ amendment in soil (soil was also applied with $2 \%$ cow manure as fertilizer), did not reduce the accumulation of $\mathrm{Zn}, \mathrm{Cu}, \mathrm{Ni}$ and $\mathrm{Fe}$ in spinach irrigated with municipal sewage sludge effluent. However, the NUE (nutrient use efficiency) for $\mathrm{Zn}$ and $\mathrm{Cu}$ was significantly higher in the plants grown in biochar amended soils and irrigated with wastewater, which indicates that these plants accumulated less $\mathrm{Zn}$ and $\mathrm{Cu}$ per weight biomass production. There was no trend for heavy metal accumulation in leaves of spinach regarding biochar particle size or application rate. This suggest that despite of small size, biochar did not cause any reduction in the bioavailability of heavy metals to plants grown under wastewater irrigation. The bioaccumulation factor (or bioconcentration factor) of heavy metals in aboveground plant biomass of spinach was not in accordance to the concentration of these heavy metals in water samples. For instance, the concentration of $\mathrm{Zn}$ in wastewater was approximately 14 times greater than $\mathrm{Ni}$ but the bioaccumulation factor for $\mathrm{Zn}$ was 6-8 times lower than for Ni. Our results are not in agreement with the findings of Yabanli et al. (2014) in this regard. Our 
results indicate that homeostasis for uptake of heavy metals may had played a role and plants might had acquired these metals within their metabolic capacity.

\section{Conclusions}

The main conclusions of this study are as follows:

1) Wastewater improved plant growth performance in terms of aboveground biomass production, leaf area, WUE, root growth and accumulation of soil in rhizosphere, which is an indication of rhizosphere secretions.

2) The amendment of wood-derived biochar in soil promoted plant growth performance especially under groundwater irrigation, while in wastewater-irrigated soil biochar reduced the leaf area of spinach. Despite of higher biomass production, reduced leaf area index indicates that biochar promoted stem biomass under wastewater irrigation. As leaf is the edible part of spinach, biochar amendment reduced production of leaf under wastewater irrigation.

3) Rhizosphere soil was significantly higher of the plants irrigated with wastewater with or without biochar amendment as compared to groundwater irrigation control treatment, however the rhizosphere soil:root biomass ratio was not higher. The rhizosphere soil is an indication of secretions of roots and rhizosphere microorganisms. The lower rhizosphere soil:root biomass ratio in plants under wastewater irrigation than groundwater irrigation treatment may indicate lower microbial abundance or lower root secretions. This factor merits further investigation as it has implications in plant resistance to diseases, nutrient cycling, soil carbon sequestration (as soil aggregation) and crop yield.

4) Application of biochars at all amendment rates significantly reduced the concentration of $\mathrm{Cu}$ in aboveground plant biomass under wastewater irrigation. Moreover, the NUE of plants for $\mathrm{Cu}$ and $\mathrm{Zn}$ was higher in biochar-amended soil under wastewater irrigation, which indicates that plants grown in biochar-amended soils acquired less heavy metals per weight of biomass production under wastewater irrigation. This finding indicates that biochar amendment tend to reduce the accumulation of heavy metals in spinach under wastewater irrigation.

\section{Acknowledgements}

This research is funded by the Balochistan Educational Endowment Fund Program.

\section{References}

Aller, D., Rathke, S., Laird, D., Cruse, R., \& Hatfield, J. (2017). Impacts of fresh and aged biochars on plant available water and water use efficiency. Geoderma, 307, 114-121. https://doi.org/10.1016/j.geoderma.2017.08.007
Ameloot, N., Sleutel, S., Case, S. D. C., Alberti, G., McNamara, N. P., Zavalloni, C., Vervisch, B., Vedove, G., \& Neve, S. D. (2014). C mineralization and microbial activity in four biochar field experiments several years after incorporation. Soil Biology and Biochemistry, 78, 195-203. https://doi.org/10.1016/j.soilbio.2014.08.004

Baltrènaite, E., Baltrènas, P., \& Lietuvninkas, A. (2016). Use of wood products for water and soil quality improvement. In The sustainable role of the tree in environmental protection technologies (pp. 185-248). Springer International Publishing Switzerland. https://doi.org/10.1007/978-3-319-25477-7_6

Chintala, R., Schumacher, T. E., McDonald, L. M., Clay, D. E., Malo, D. D., Papiernik, S. K., Clay, S. A., \& Julson, J. L. (2014). Phosphorus sorption and availability from biochars and soil/ biochar mixtures. CLEAN Soil Air Water, 42(5), 626-634. https://doi.org/10.1002/clen.201300089

Dharmakeerthi, R., Chandrasiri, J., \& Edirimanne, V. (2012). Effect of rubber wood biochar on nutrition and growth of nursery plants of Hevea brasiliensis established in an Ultisol. SpringerPlus, 1(1), 1-12. https://doi.org/10.1186/2193-1801-1-84

Estefan, G., Sommer, R., \& Ryan, J. (2013). Methods of soil, plant, and water analysis: a manual for the West Asia and North Africa region. International Center for Agricultural Research in the Dry Areas (ICARDA), Beirut, Lebanon.

Gul, S., \& Whalen, J. K. (2013). Phenology, morphology, aboveground biomass and root-associated soil respiration of Arabidopsis thaliana down-regulated cell wall mutants of MYB75, KNAT7, and CCR1. Pedobiologia, 56(2), 69-77. https://doi.org/10.1016/j.pedobi.2012.11.001

Gul, S., Whalen, J. K., Thomas, B. W., Sachdeva, V., \& Deng, H. (2015). Physico-chemical properties and microbial responses in biochar-amended soils: mechanisms and future directions. Agriculture, Ecosystems and Environment, 206, 46-59. https://doi.org/10.1016/j.agee.2015.03.015

Gul, S., \& Whalen, J. K. (2016). Biochemical cycling of nitrogen and phosphorus cycling in biochar-amended soils. Soil Biology and Biochemistry, 103, 1-15.

https://doi.org/10.1016/j.soilbio.2016.08.001

Li, P., Hu, C., Qi, X., Zhou, Y., Jianfeng, Z., \& Zia, Z. (2015). Effect of reclaimed municipal wastewater irrigation and nitrogen fertilization on yield of tomato and nitrogen economy. Bangladesh Journal of Botany, 44(5), 699-708.

Liu, C., Liu, F., Ravnskov, S., Rubaek, G., Sun, Z., \& Andersen, M. (2016). Impact of wood biochar and its interactions with mycorrhizal fungi, phosphorus fertilization and irrigation strategies on potato growth. Journal of Agronomy and Crop Science, 203(2), 131-145. https://doi.org/10.1111/jac.12185

Lucchini, P., Quilliam, R. S., DeLuca, T. H., Vamerali, T., \& Jones, D. L. (2014). Does biochar application alter heavy metal dynamics in agricultural soil? Agriculture, Ecosystems and Environment, 184, 149-157. https://doi.org/10.1016/j.agee.2013.11.018

Lusiba, L., Odhiambo, J., \& Ogola, J. (2018). Growth, yield and water use efficiency of chickpea (Cicer arietinum): response to biochar and phosphorus fertilizer application. Archives of Agronomy and Soil Science, 64(6), 1-15. https://doi.org/10.1080/03650340.2017.1407027

Mia, S., Uddin, N., Hossain, S. A. A. M., Amin, B., Mete, F. Z., \& Hiemstra, T. (2015). Production of biochar for soil application: a comparative study of three kiln models. Pedosphere, 25(5), 696-702. https://doi.org/10.1016/S1002-0160(15)30050-3

Mensah, I. S., \& Okonwu, K. (2016). Effect of Pentaclethra macrophylla biochar on some growth indices of Capsicum Annu- 
um L. in Port Harcourt, Nigeria. European Journal of Physical and Agricultural Sciences, 4(2), 10-19.

Nigussie, A., Kissi, E., Misganaw, M., \& Ambaw, G. (2012). Effect of biochar application on soil properties and nutrient uptake of lettuces (Lactuca sativa) grown in chromium polluted soils. American-Eurasian Journal of Agricultural and Environmental Science, 12(3), 369-376.

Pivato, B., Bru, D., Busset, H., Deau, F., Matejicek, A., Philippot, L., \& Moreau, D. (2017). Positive effects of plant association on rhizosphere microbial communities depend on plant species involved and soil nitrogen level. Soil Biology and Biochemistry, 114, 1-4. https://doi.org/10.1016/j.soilbio.2017.06.018

Prendergast-Miller, M. T., Duvall, M., \& Sohi, S. P. (2013). Biochar-root interactions are mediated by biochar nutrient content and impacts on soil nutrient availability. European Journal of Soil Science, 65(1), 173-185. https://doi.org/10.1111/ejss.12079

Qureshi, A. S., Hussain, M. I., Ismail, S., \& Khan, Q. M. (2016). Evaluating heavy metal accumulation and potential health risks in vegetables irrigated with treated wastewater. Chemosphere, 163, 54-61. https://doi.org/10.1016/j.chemosphere.2016.07.073

Raja, S., Cheema, H. M. N., Babar, S., Khan, A. A., Murtaza, G., \& Aslam, U. (2015). Socio-economic background of wastewater irrigation and bioaccumulation of heavy metals in crops and vegetables. Agricultural Water Management, 158, 26-34. https://doi.org/10.1016/j.agwat.2015.04.004

Rechcigl, J. E., \& Payne, G. G. (1989). Comparison of a microwave digestion system to other digestion methods for plant tissue analysis. In Annual meetings of American Society of Agronomy, Crop Science Society of America and Soil Science Society of America, Las Vegas Nevada. Retrieved from http:// www.cem.de/documents/pdf/publikation/digestion/rd026.pdf

Tahir, S., Gul, S., Ghori, S. A., Sohail, M., Batool, S., Jamil, N., Shahwani, M. N., \& Butt, M. R. (2018). Biochar influences growth performance and heavy metal accumulation in spinach under wastewaterirrigation. Cogent Food and Agriculture, 4, 1-12. https://doi.org/10.1080/23311932.2018.1467253

Wagner, A., \& Kaupenjohann, M. (2013). Suitability of biochars (pyro- and hydrochars) for metal immobilization on former sewage-field soils. European Journal of Soil Science, 65, 139148. https://doi.org/10.1111/ejss. 12090

Yamato, M., Okimori, Y., Wibowo, I. F., Anshori, S., \& Ogawa, M. (2006). Effects of the application of charred bark of Acaciamangium on the yield of maize, cowpea and peanut and soil chemical properties in south Sumatra, Indonesia. Soil Science and Plant Nutrition, 52, 489-495.

https://doi.org/10.1111/j.1747-0765.2006.00065.x

Yabanli, M., Yozukmaz, A., \& Sel, F. (2014). Heavy metal accumulation in the leaves, stem and root of the invasive submerged macrophyte Myriophyllum spicatum L. (Haloragaceae): an example of Kadın Creek (Mugla, Turkey). Brazilian Archives of Biology and Technology, 57, 434-440. https://doi.org/10.1590/S1516-8913201401962

Zhang, G., Guo, X., Zhao, Z., He, Q., Wang, S., Zhu, Y., Yan, Y., Liu, X., Sun, K., Zhao, Y., \& Qian, T. (2016). Effects of biochars on the availability of heavy metals to ryegrass in an alkaline contaminated soil. Environmental Pollution, 218, 513522. https://doi.org/10.1016/j.envpol.2016.07.031 